\title{
Distribution of carbon stocks in drainage areas on peatlands of Sungai Tohor Village, Meranti Islands District, Indonesia
}

\author{
SINTA HARYATI SILVIANA ${ }^{1, \boldsymbol{v}}$, BAMBANG HERO SAHARJO ${ }^{2}$, SIGIT SUTIKNO ${ }^{3}$ \\ ${ }^{1}$ Tropical Silviculture Program, Graduate School, Faculty of Forestry and Environment, Institut Pertanian Bogor. Jl. Lingkar Akademik, IPB University \\ Campus Dramaga, Bogor 16680, West Java, Indonesia. Tel./fax.: +62-251-8628448, • email: sintaharyatis@gmail.com \\ ${ }^{2}$ Department of Silviculture, Faculty of Forestry and Environment, Institut Pertanian Bogor. J1. Ulin, IPB University Campus Dramaga, Bogor 16680, \\ West Java, Indonesia \\ ${ }^{3}$ Department of Civil Engineering, Faculty of Engineering, Universitas Riau. Jl. Pekanbaru-Bangkinang Km 12.5, Kampus Bina Widya Panam, Simpang
} Baru, Pekanbaru 28293, Riau, Indonesia

Manuscript received: 18 September 2021. Revision accepted: 27 October 2021.

\begin{abstract}
Silviana SH, Saharjo BH, Sutikno S. 2021. Distribution of carbon stocks in drainage areas on peatlands of Sungai Tohor Village, Meranti Islands District, Indonesia. Biodiversitas 22: 5106-5114. Peatland ecosystems provide a variety of environmental services and biodiversity with their ability to store and absorb carbon. The increase of land clearing followed by the construction of drainage or canal has resulted in the degradation of peatlands and is prone to fire incidences. Canal construction, whether we realize it or not, has a negative ecological impact on the in situ (local) environment, namely land degradation and subsidence, as well as a wider (global) impact in the form of loss of carbon stocks, increased GHG emissions that can trigger global warming. This study aims to identify the distribution of carbon in the area where drainage is made where the distribution of carbon stock in starting at a distance of $10 \mathrm{~m}, 50 \mathrm{~m}, 100 \mathrm{~m}, 250 \mathrm{~m}$, and $350 \mathrm{~m}$ from the canal. The study was conducted on the community plantations including unburned areas (rubber plantations and secondary forests) and burned areas. The influence of land use and drainage development on carbon stock distribution is rarely known. The results showed a decrease in C-Stock with a decrease in drainage distance. The quantity of carbon stock in secondary forests ranged from 13.275 ton ha $\mathrm{ha}^{-1}-24.839$ ton ha ${ }^{-1}$, Burnt Area-1 ranged from 6.995 ton ha ${ }^{-1}-11.59$ ton ha ${ }^{-1}$, and Burnt Area 2 ranged from 4.677 ton $\mathrm{ha}^{-1}-12.580$ ton ha ${ }^{-1}$. In contrast, rubber plantations had higher C-stock in the initial observation distance, around 9.064 ton ha- -11.805 ton $\mathrm{ha}^{-1}$, which may be due to intensive land use near the canal.
\end{abstract}

Keywords: Biomass, carbon, distance, canal, land use

\section{INTRODUCTION}

Peat swamps are defined as terrestrial wetland ecosystems where organic material production exceeds decomposition resulting in net accumulation (Page et al. 2007; Sulman et al. 2012). A peat swamp is a comprehensive whole with various functions that influence each other in shaping balance, stability, and productivity (Rieley et al. 2008). Peat swamp forest has a function as a climate controller through its ability to absorb and store carbon (C) in the form of biomass (Muslihat et al. 2009). The C reserves of the largest peatland ecosystem in the world are stored above and below the soil surface (Page et al. 2011; Basuki et al. 2018). Total $\mathrm{C}$ contained in tropical peatlands is estimated to range between 81.7 to $91.9 \mathrm{Pg}$ or around 15$19 \%$ of global peat $\mathrm{C}$ reserves $(610 \mathrm{Pg})$ where Indonesia stores around $57 \mathrm{Pg}$ (Verwer and Meer 2010).

One of the key factors in peatland sustainability is strongly influenced by the hydrological system (Page et al. 2011). At present, the increasingly widespread human activity in peatlands, including the activity of making drainage or canal is reported to disrupt the area's hydrological balance (Huijnen et al. 2016; Koh et al. 2011). An excessive drainage system through peat swamps is reported to dry out the concerned area Clement et al. (2015). Poor drainage construction without regard to ecological conditions triggers accelerated subsidence of peat soils and ecosystem changes. Changes in this ecosystem cause changes in the characteristics and physical, chemical, and biological characteristics of the soil (Sutarta et al. 2006). Excessive drying with drainage directly impacts the decrease in groundwater level (Huijnen et al. 2016; Koh et al. 2011). Drainage development causes the function of peat hydrological systems as reservoirs and water management to be reduced or even lost (Radjagukguk 1997; Runtunuwu et al. 2011). In addition, continuous drainage results in an irreversible drying process. As a result, the area becomes flooded in the rainy season and has drought-like conditions in the dry season, making it prone to fire incidences (Ritzema 2007).

Drainage on peatlands in addition to making peatlands vulnerable to fire also leads to carbon emissions. In the case of natural forests, peatlands function as carbon sequesters so that they contribute to reducing greenhouse gases in the atmosphere, even though the mooring process runs very slowly as high as 0-3 mm of peat per year (Parish et al. 2007) or equivalent to tethering 0-5.4 $\mathrm{t} \mathrm{CO}_{2}$ ha year ${ }^{-1}$ (Agus 2009). When peat forests are drained, carbon stored in peat is easily oxidized to $\mathrm{CO}_{2}$ (one of the most important greenhouse gases). According to Hooijer (2006), 50\% of emissions in Indonesia are due to drainage and changes in peatland 
management; the rate of emissions is significant with drainage depth.

The use of drainage for agricultural systems affects carbon emissions due to oxidation-reduction activities of organic material from the peat (Agus and Subiksa 2008). This changes anaerobes (water saturation) to aerobes (water unsaturation), thereby increasing the rate of decomposition and $\mathrm{CO}_{2}$ emissions. The high activity of land use close to drainage can affect the available $\mathrm{C}$-stock. Thus, drainage made for area management has an impact on the quantity of biomass. The conversion of peat forest to other forms of use followed by the construction of drainage channels/canals will cause enormous carbon losses and contribute to GHG emissions and climate change (Canadell et al. 2007).

On intensely planted plantations are known to have increased biomass production. The number of biomass between areas varies, depending on the diversity and density of existing plants, soil types, and how they are managed (Hairiah et al. 2011). In this study, an analysis of carbon stocks was obtained through the addition of biomass content of both aboveground biomass, belowground biomass, understorey, and necromass (Ariani and Wahid 2014). Biomass is the total dry weight of vegetation above ground level. The biomass of the sapling, pole and tree level is influenced by the diameter factor. C-stock can be known using the allometric equation Manuri et al. (2014), Lubis et al. (2011), and Hairiah et al. (2011). The carbon content in forests can be estimated using estimates of forest biomass because about $50 \%$ of forest biomass is composed of $\mathrm{C}$ (Brown et al. 1997).

In the process of photosynthesis, $\mathrm{CO}_{2}$ in the atmosphere is bound by forest vegetation and stored as biomass. The main sources of $\mathrm{C}$ in forest ecosystems are tree biomass, undergrowth, litter, dead wood, and soil organic matter (Gibbs et al. 2007). Therefore, the measurement of forest biomass can be used to estimate potential $\mathrm{C}$ reserves and is the most critical step in determining $\mathrm{C}$ forest reserves. (Gibbs et al. 2007). Based on Intergovernmental Panel on Climate Change (IPCC), The $\mathrm{C}$ fraction used to calculate the C content of forest biomass is 0.47 (IPCC 2006). The carbon contained in plant biomass is the result of tethering through the process of photosynthesis. Some of the carbon produced during photosynthesis will be lost in the form of respiration, so the number of carbon stored in biomass is the difference between the two processes. The number of carbon stored in biomass in an area varies depending on the age and type of plants, diversity, and density of plants, soil fertility, climatic conditions, altitude, and area management. The more appropriate the area conditions for plants, the higher the rate of photosynthesis, and the higher the productivity in absorbing carbon. In this study, carbon levels will be seen along with the distance from drainage. In the framework of climate change mitigation, the calculation, absorption, stock and emission of carbon in the forestry sector is very important. Data on carbon stocks stored in the form of biomass in a vegetation area is needed in the development of a carbon sink program. This is the most basic in formulating a strategy for reducing GHG emissions.

\section{MATERIALS AND METHODS}

\section{Study area and period}

The study was conducted in Sungaitohor Village, Tebingtinggi Timur District, Kepulauan Meranti District (Figure 1), from November 2018 - May 2019. Sungai Tohor village is located at coordinates 0048'35"-0058'19" North Latitude and 102049'10"-102058'3" East Longitude. Sungai Tohor Village is one of the villages in Tebing Tinggi Timur sub-district, Meranti Islands Regency, Riau province, Indonesia. Sungaitohor Village is famous for being the largest producer of sago in Tebingtinggi Timur Subdistrict (BPS Kabupaten Meranti 2014). In this village, sago cultivation has flourished up to 2650 hectares and has been a source of the community's economy since 1970 (Profile of Sungaitohor Village 2018).

In early to mid-2014, a large fire occurred in this sagoproducing center. The subsequent land clearing followed by the construction of drainage channels, especially in the peat dome, has caused excessive water drainage leading to peat degradation. The construction of drainage channels or often referred to as canals, cause the peat in this area to become dry and susceptible to fire. Canal construction is an activity carried out in the early stages of land clearing which is then followed by land preparation. The canals are made to transport wood and drain the land so that it can be planted with Acacia and optimum conditions for its growth can be achieved. The construction of a very wide canal (5 m - $7 \mathrm{~m}$ ) also drains peat water into the sea, thereby changing the peat ecosystem to become increasingly damaged.

\section{Research design}

Data collection and measurement were carried out directly in the field by making permanent plots. This research was conducted on the various types of land use namely rubber plantations, secondary forests, and burned areas. Data was collected by making two separate transect lines in a single canal flow on each area used. Distances from the drainage of $10 \mathrm{~m}, 50 \mathrm{~m}, 150 \mathrm{~m}, 250 \mathrm{~m}$, and $350 \mathrm{~m}$ are made perpendicular to the drainage.

Calculations were carried out on aboveground biomass, dead aboveground biomass such as litter and fallen branches, and biomass in the soil consisting of plant roots.

Aboveground biomass measurements were estimated using two field methods namely destructive and nondestructive methods. Measurements using the destructive method were carried out with the harvesting method of forest ecosystem biomass (Gibs et al. 2007). In this study, harvesting was conducted only in the undergrowth with stems, branches, and leaves and measuring its dry weight (after it was roasted) (Chung-Wang and Ceulemans 2004; Ravindranath and Oswald 2008). In non-destructive diameter data at breast height $(\mathrm{DBH})$ was measured along with belowground biomass from the roots of each plant with a correction factor.

The carbon calculation was adjusted to the SNI document 7724 of 2011 for the estimation of forest carbon reserves (ground-based forest carbon accounting). All species in the plot were recorded with their species names (local and scientific). Variables measured for tree-level 
include diameter, height, species name, and several individuals. Tree circumference $(\mathrm{C})$ was measured at the height of $1.3 \mathrm{~m}$ from ground level, to obtain diameter data at breast height $(\mathrm{DBH})$. Diameter data were obtained from stem diameters according to the criteria above and calculated using the formula $\mathrm{D}=\mathrm{C} / 3.14$.

\section{Calculation of carbon from biomass}

Calculation of $\mathrm{C}$ from biomass uses the following equation (SNI 7724:2011):

$$
\mathrm{C}=\mathrm{B} \times \% \mathrm{C} \text { organic }
$$

Where:

$\mathrm{C}=$ Carbon content of biomass, in kilograms $(\mathrm{kg})$

$\mathrm{B}=$ Total biomass, expressed in $(\mathrm{kg})$;

$\% \mathrm{C}$ organic $=$ Percentage value of carbon content, numbering to 0.47 or using the value of percent carbon obtained from laboratory measurements

\section{Calculation of carbon stock per hectare in each plot}

Calculation of total $\mathrm{C}$ reserves per hectare for aboveground biomass uses the following equation (SNI 7724:2011):

$$
\mathrm{Cn}=\left(\frac{\mathrm{C}_{\mathrm{X}}}{1000} \times \frac{10000}{\text { lplot }}\right)
$$

Where:

$\mathrm{C}_{\mathrm{n}} \quad=$ reserve $\mathrm{C}$ per hectare in each carbon pool in each plot (ton $\mathrm{C} \mathrm{ha}^{-1}$ )

$\mathrm{C}_{\mathrm{x}}=$ the $\mathrm{C}$ content in each carbon pool in the plot $(\mathrm{kg})$ $1_{\text {plot }}=$ area of plot in each pool, expressed in square meters $\left(\mathrm{m}^{2}\right)$

\section{Total $\mathrm{C}$ reserves in the plot}

The calculation of carbon stocks in the measurement plot uses the following equation:

$\mathrm{C}_{\text {Plot }}=\left(\mathrm{C}_{\mathrm{bap}}+\mathrm{C}_{\mathrm{bbp}}+\mathrm{C}_{\mathrm{tb}}+\mathrm{C}_{\mathrm{s}}+\mathrm{C}_{\mathrm{km}}+\mathrm{C}_{\mathrm{pm}}\right)$

Where:

$\mathrm{C}_{\text {Plot }}=$ total carbon content in the plot $\left(\right.$ ton $\left.\mathrm{C} \mathrm{ha}^{-1}\right)$

$\mathrm{C}_{\mathrm{bap}}=$ total carbon content of aboveground biomass (ton $\mathrm{C} \mathrm{ha}^{-1}$ )

$\mathrm{C}_{\mathrm{bbp}}=$ total carbon content of belowgroud biomass (ton $\mathrm{C} \mathrm{ha}^{-1}$ )

$\mathrm{C}_{\mathrm{tb}}=$ total litter carbon content (ton $\mathrm{C} \mathrm{ha}^{-1}$ )

$\mathrm{C}_{\mathrm{s}}=$ total carbon content of dead trees (tons $\mathrm{C} \mathrm{ha}^{-1}$ )

$\mathrm{C}_{\mathrm{km}}=$ total carbon content of dead wood (tons $\mathrm{C} \mathrm{ha}^{-1}$ )

$\mathrm{C}_{\mathrm{pm}}=$ total plant carbon content (ton $\mathrm{C} \mathrm{ha}^{-1}$ )

\begin{tabular}{|c|c|c|c|c|}
\hline $\begin{array}{l}\text { Component } \\
\text { biomass }\end{array}$ & Definition & Method & Size plot & Types of data collected \\
\hline Tree & $\begin{array}{l}\text { Sapling diameter }<5 \mathrm{~cm} \\
\text { Pole diameter } 5-10 \mathrm{~cm} \\
\text { Tree diameter }>20 \mathrm{~cm}\end{array}$ & Non destructive & $\begin{array}{l}5 \mathrm{~m} \times 5 \mathrm{~m} \\
10 \mathrm{~m} \times 10 \mathrm{~m} \\
20 \mathrm{~m} \times 20 \mathrm{~m}\end{array}$ & Type name, diameter (DBH) \\
\hline Seedlings & $\begin{array}{l}\text { All vegetation that grows on the forest } \\
\text { floor is herbal, bush or liana }\end{array}$ & Destructive & $2 \mathrm{~m} \times 2 \mathrm{~m}$ & $\begin{array}{l}\text { Total wet weight, sample wet } \\
\text { weight, sub-sample dry weight. }\end{array}$ \\
\hline \multirow[t]{2}{*}{ Necromass } & $\begin{array}{l}\text { Litter: All organic material on the forest } \\
\text { floor has not been completely decomposed. }\end{array}$ & Destructive & $2 \mathrm{~m} \times 2 \mathrm{~m}$ & $\begin{array}{l}\text { Total wet weight, sample wet } \\
\text { weight, dry weight }\end{array}$ \\
\hline & $\begin{array}{l}\text { Dead tree: All standing dead trees or dead } \\
\text { wood or fallen parts of trees including } \\
\text { stems, branches, and twigs. }\end{array}$ & Destructive & $20 \mathrm{~m} \times 20 \mathrm{~m}$ & $\begin{array}{l}\text { Diameter (DBH), tip diameter, } \\
\text { base diameter, height, wood } \\
\text { density. }\end{array}$ \\
\hline
\end{tabular}

Table 1. Measurement of plant biomass

\begin{tabular}{|c|c|c|c|c|}
\hline $\begin{array}{c}\text { Components } \\
\text { biomass }\end{array}$ & Category & $\begin{array}{c}\text { The equation for calculating } \\
\text { biomass }\end{array}$ & Explanation & $\begin{array}{c}\text { Data } \\
\text { generated }\end{array}$ \\
\hline Tree & $\begin{array}{l}\text { Aboveground } \\
\text { biomass } \\
\text { Belowground } \\
\text { biomass }\end{array}$ & $\begin{array}{l}\mathrm{Y}=0.242 \times \mathrm{DBH}^{2.473} \times \mathrm{WD}^{0.736} \\
(\text { Manuri et al. } 2014) \\
\mathrm{B}_{\text {root }}=0.37 \times \mathrm{BGB}\end{array}$ & $\begin{array}{l}\text { Y= Biomass per tree }(\mathrm{kg}) \\
\text { D: DBH }(\mathrm{cm}) \\
\text { B }_{\text {root }} \text { : Root biomass }(\mathrm{kg}) \\
\text { AGB: Aboveground biomass }(\mathrm{kg})\end{array}$ & $\begin{array}{l}\text { Biomass per } \\
\text { tree }(\mathrm{kg})\end{array}$ \\
\hline \multirow{3}{*}{$\begin{array}{l}\text { Seedlings } \\
\text { Necromass }\end{array}$} & $\begin{array}{l}\text { Aboveground } \\
\text { biomass }\end{array}$ & $\mathrm{Bo}=\frac{\mathrm{Bks} \times \mathrm{Bbt}}{\mathrm{Bbs}}$ & $\begin{array}{l}\text { Bo: Weight of organic matter }(\mathrm{kg}) \\
\text { Bks: Dry weight sample }(\mathrm{kg})\end{array}$ & $\begin{array}{l}\text { Biomassa } \\
\text { per plot }(\mathrm{kg})\end{array}$ \\
\hline & $\begin{array}{l}\text { Aboveground } \\
\text { biomass }\end{array}$ & $\begin{array}{l}\text { Litter } \\
\qquad B o=\frac{B k s \times \mathrm{Bbt}}{\mathrm{Bbs}}\end{array}$ & $\begin{array}{l}\text { Bbt: Total wet weight }(\mathrm{kg}) \\
\text { Bbs: Wet sample weight }(\mathrm{kg})\end{array}$ & $\begin{array}{l}\text { Biomass } \\
\text { per plot }(\mathrm{kg})\end{array}$ \\
\hline & & $\begin{array}{l}\text { Dead tree } \\
\text { DBH the tree dies, then sees the } \\
\text { shape of the integrity of the tree }\end{array}$ & $\begin{array}{l}\text { The level of integrity with correction } \\
\text { factors: (A) } 0.9 \text {, (B) } 0.8 \text {, and (C) } 0.7\end{array}$ & $\begin{array}{l}\text { Biomass per } \\
\text { plot }(\mathrm{kg})\end{array}$ \\
\hline
\end{tabular}

Table 2. Biomass calculation 


\section{RESULTS AND DISCUSSION}

\section{Climate}

Climate is a general weather condition in a region for a long period. Chandler et al. (1983) state that weather and climate affect forest fires in some interrelated ways. The climate in each region will determine the type of fuel and the length of the fire season. Also, climate plays an important role in the rate of decomposition of organic matter, so that when the temperature humidity increases, the decomposition process also takes place quickly. Climate change due to weather will affect fire, fire behavior, and carbon emissions due to fire (de Groot et al. 2013). According to the Koppen classification, the area of Sungaitohor Village is classified under tropical climates with high-temperature (at sea level or low altitude). The temperature between $25-32^{\circ} \mathrm{C}$ or with an average annual temperature is $26.6^{\circ} \mathrm{C}$ and the average annual rainfall is $2269 \mathrm{~mm}$ (https://en.climatedata.org/location/569076/).

The availability of groundwater is strongly influenced by the amount of rainfall and water seepage into the ground, where the increase in the volume of water will stop as rain stops. Calculation of estimated rainfall and number of rainy days is done using the Tropical Rainfall Measuring Mission (TRMM) satellite. The results of data processing in January 2004 - December 2018 show the amount of rainfall volume ranges from 1379-1910 mm/year or with an average of 1618 $\mathrm{mm} /$ year with a pattern of monthly rainfall volume that is "bimodal" or with two peaks of the rainy season (Figure 2 ). The peak of the first rainy season is in April (174 $\mathrm{mm} / \mathrm{month}$ ) and the second rainy season in November (204 $\mathrm{mm} / \mathrm{month}$ ).

Weather greatly influences how, where, and when forest fires can occur (Fuller 1991). Weather can regulate water content and ease of fuel to burn. The availability of water in a study area is described by the volume of rainfall, while the potential for temporal distribution of water is expressed by the number of rainy days. According to the Oldeman climate zone classification (Oldeman et al. 1979) based on the criteria for the number of wet and dry months, which are divided into three criteria, showed that Sungaitohor Village has three wet months, with more than $200 \mathrm{~mm}$ of rainfall, so that this region is more suitable to be included in the $\mathrm{E}$ zone. Leng et al. (2015) stated that due to climate change in the dry season, it can cause more severe and prolonged drought. Based on the average number of rainy days for the period of 15 years (2004-2008), the number of rainy days/ month was found to range between 5-19 days (Figure 3).

\section{Number of plant individuals with drainage distance}

In this study, it was seen a large number of individuals were found with increasing distances in drainage. The results showed an increase in the number of individuals with increasing distance from the canal in both burnt and unburnt areas. Based on the results of the correlation analysis, a high correlation was observed between distance and the number of individuals (Figure 4$)$ on the unburned area $\left(\mathrm{R}^{2}=0.983\right.$ ) and on (Figure 5) on the unburnt area $\left(\mathrm{R}^{2}=0.9787\right)$. The high correlation value in the two types of the area indicated a close and positive relationship between the distance from the canal and the number of individuals. The further away from the canal, the number of individuals found was also increased (at the start point of observation $10 \mathrm{~m}$ and the endpoint of observation $350 \mathrm{~m}$ ).

The number of individuals found is related to the ease of use of the area. Lillesand and Kiefer (1990) say that land use is related to human activities. The number of individuals in the area near the drainage was found to be easily accessible. Mulyasana (2008) stated that a smaller number of individual plants could also occur due to interference from humans.
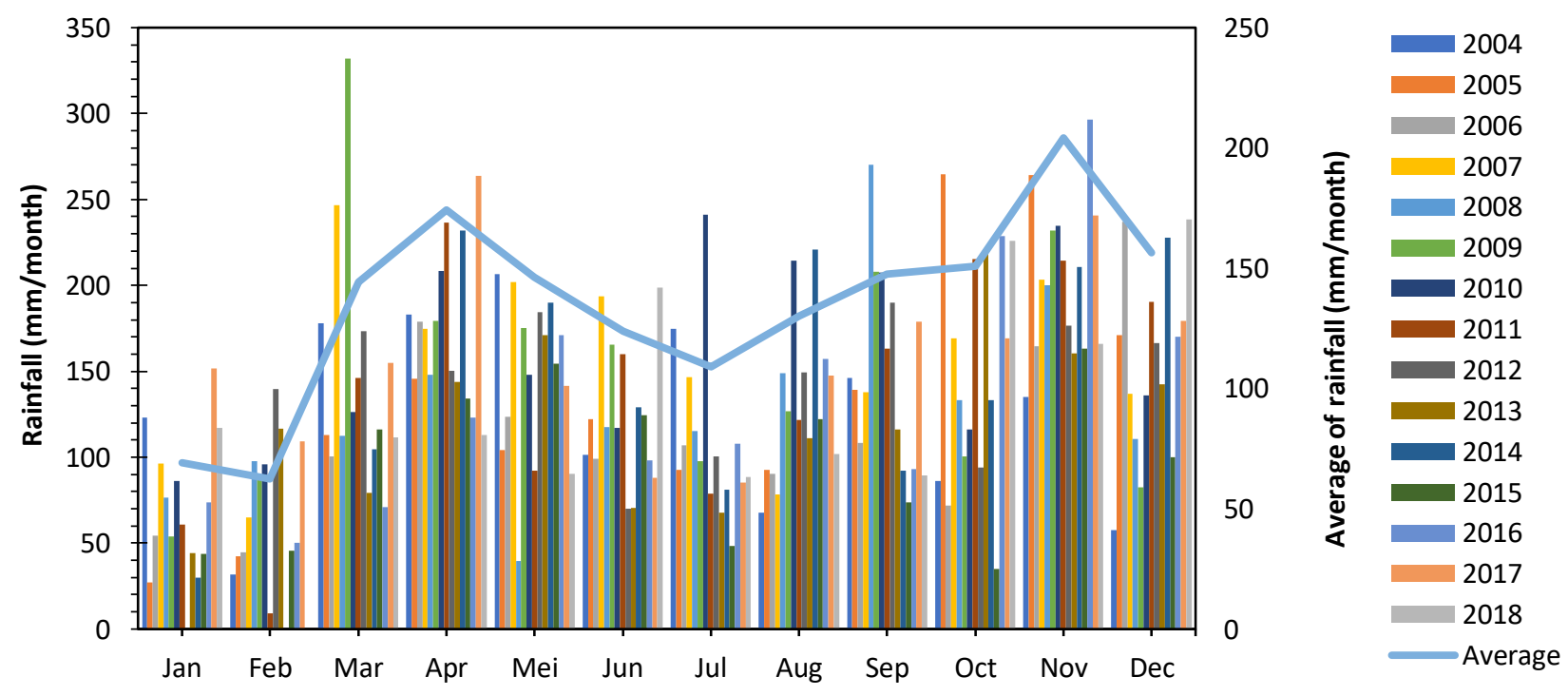

Figure 1. The pattern of rainfall volume in the study area. The histogram shows variation over 15 years (2004-2018), while the curve shows the mean 

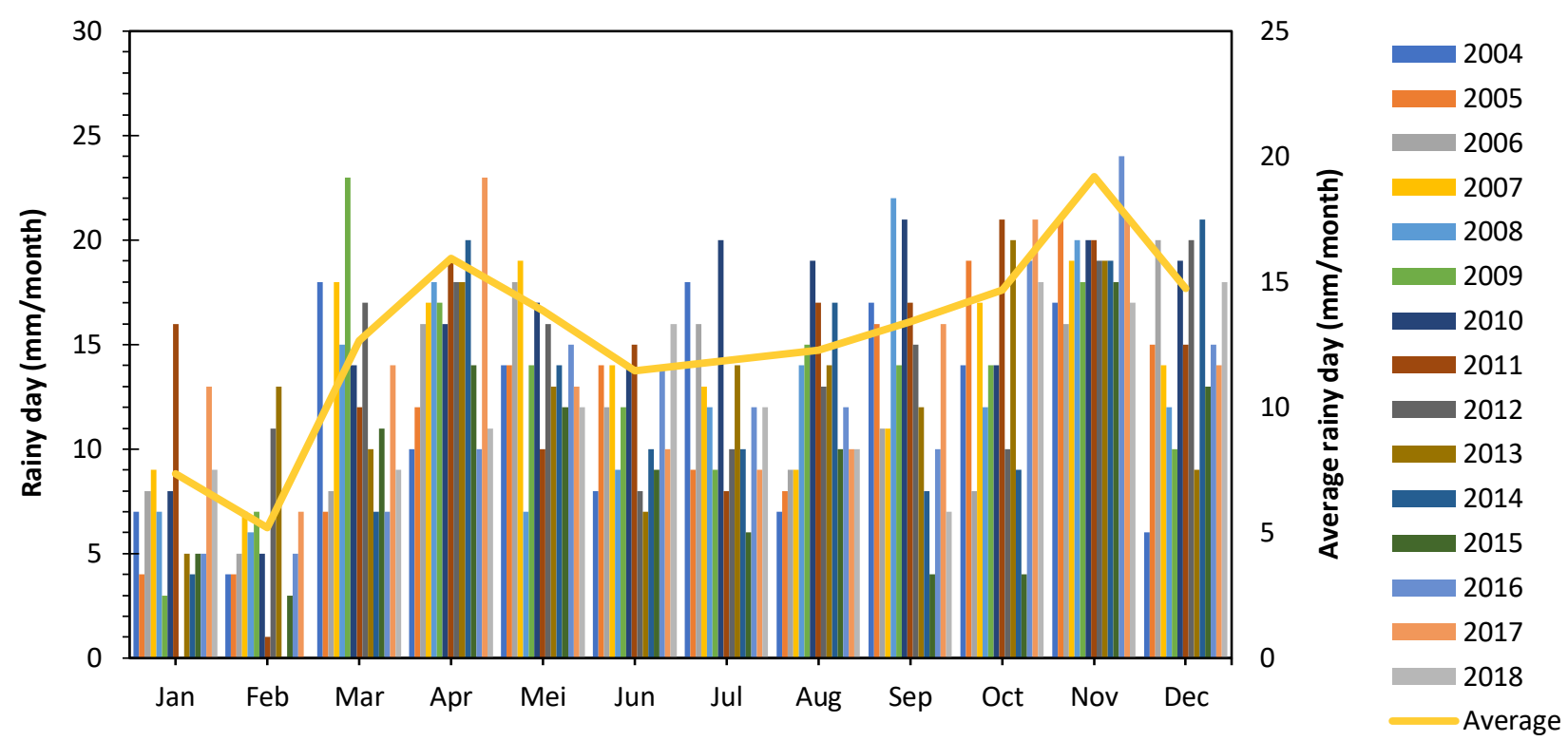

Figure 3. The pattern of the number of rainy days in the study area. The histogram shows variation over 15 years (2004-2018), while the curve shows the mean

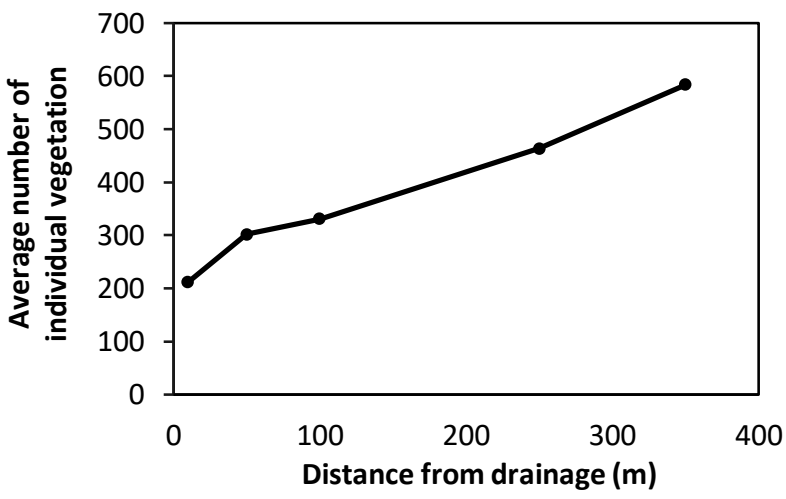

Figure 4. The average number of individual vegetation found in the unburned area

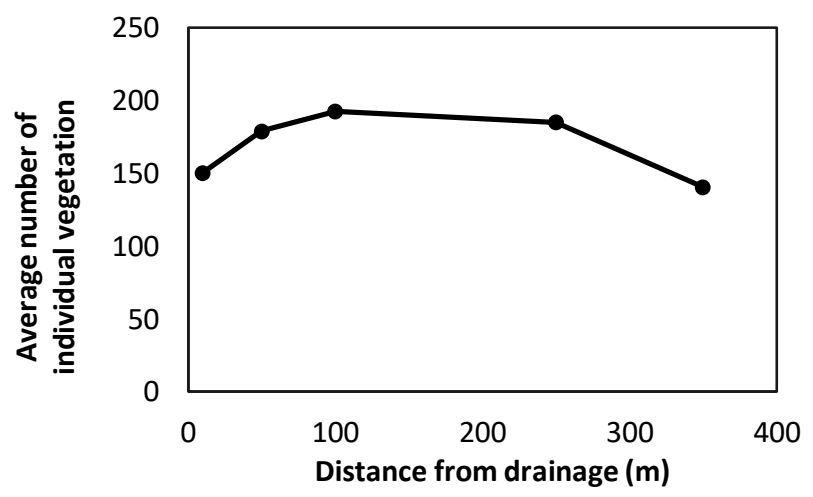

Figure 5. The average number of individual vegetation found in the burnt area

\section{Quantity of carbon stocks at a distance from drainage}

In this study, an analysis of carbon stocks was carried out on all types of areas used in the study area. The total calculation was obtained from the results of biomass content such as aboveground biomass, belowground biomass, cover crop, and necromass (Ariani and Wahid 2014). Biomass is the total dry weight of vegetation where the number of biomass is influenced by the diameter factor. The calculation results obtained are presented in (Table 1). Also, litter produced by vegetation will contribute to the provision of biomass and improve the condition of peat soils as a nutrient provider (Arifin 2010).

In rubber plantations, the biomass content was found to fluctuate between each measurement distance (Figure 6). The highest total C-stock at the first observation distance (10 m) was 11.805 ton $\mathrm{ha}^{-1}$ and on the second observation (a distance of $50 \mathrm{~m}$ ) it was 11.804 tons ha $^{-1}$. At a later distance, the rubber plantations were relatively smaller. The high planting of rubber at the distance of the initial observation made a lot of available biomass. Tresnawan and Roslina (2002) stated that one of the factors that influence the number of biomass to the density of a stand. Based on the results of the analysis of the correlation of biomass and carbon stocks with the distance of the observation plot of the canal, a moderate correlation was found between them $\left(R^{2}=\right.$ 0.637; Figure 7). This indicated that the relationship between distance and the number of stored biomass or carbon stock with the distance from the canal be moderately strong.

In secondary forests, the number of C-stock tend to fluctuate (13.275-24.839 ton ha $\left.{ }^{-1}\right)$ but the range tends to increase with increasing distance (Figure 8). The number of $\mathrm{C}$-stock in this secondary forest was related to the number of individuals found in each measurement plot at various levels of growth. High-density values at the level of trees, saplings, and poles, and seedlings were found to make a large contribution to the potential of bound carbon which was 
closely related to the number of the biomass of a tree. The farther away from drainage the more trees that had large diameter, thus affecting the calculation of biomass. Calculations using allometric equations that use this diameter were found to affect the results of biomass calculations (Rahayu et al. 2007). This observation was supported by Yahmani (2013) who stated that the larger the diameter of the plant, the greater the biomass and vice versa. Based on the results of carbon stock analysis with observational plot distances from drainage, a strong correlation $\left(\mathrm{R}^{2}=0.7398\right)$ was found (Figure 9$)$, meaning that the farther from the drainage, the higher the available $\mathrm{C}$ stock. So this indicated that the relationship between distance with the amount of biomass or C-stock of stored vegetation was strong.

On Burnt Area-1, the C-stock was found to be fluctuating, but the average tends to increase i.e. 6.99511.590 ton $^{-1}$ (Figure 10). The lowest number of biomass was found at a location close to drainage at the initial observation distance $(10 \mathrm{~m})$, while the highest biomass was found at the farthest observation distance $(350 \mathrm{~m})$ from the drainage. This was directly related to the number of carbon stocks available. Based on the results of the carbon stock correlations with observational plot spacing from drainage, the results were moderately small $\left(\mathrm{R}^{2}=0.5902\right.$; Figure 11$)$. At a distance of $(350 \mathrm{~m})$ from the last measurement plot, the number of C-stock was found to increase by 11.590 ton ha 1.

Table 3. The number of C-Stock in each area use.

\begin{tabular}{|c|c|c|c|c|}
\hline \multirow{2}{*}{$\begin{array}{l}\text { Distance } \\
\text { (m) }\end{array}$} & \multicolumn{4}{|c|}{ Carbon content measurement (ton ha' $\left.{ }^{-1}\right)$} \\
\hline & $\begin{array}{l}\text { Above } \\
\text { ground }\end{array}$ & $\begin{array}{l}\text { Below } \\
\text { ground }\end{array}$ & Necromass & Total \\
\hline \multicolumn{5}{|c|}{ Rubber plantation } \\
\hline 10 & 5.516 & 1.946 & 4.343 & 11.805 \\
\hline 50 & 2.717 & 0.736 & 7.631 & 11.084 \\
\hline 100 & 3.853 & 1.250 & 4.544 & 9.647 \\
\hline 250 & 2.513 & 0.490 & 7.445 & 10.448 \\
\hline 350 & 4.236 & 1.396 & 3.432 & 9.064 \\
\hline \multicolumn{5}{|c|}{ Secondary forest } \\
\hline 10 & 6.701 & 2.189 & 9.455 & 18.345 \\
\hline 50 & 5.229 & 1.608 & 8.873 & 15.710 \\
\hline 100 & 6.841 & 2.352 & 4.082 & 13.275 \\
\hline 250 & 15.055 & 5.085 & 3.690 & 23.830 \\
\hline 350 & 13.805 & 4.873 & 6.161 & 24.839 \\
\hline \multicolumn{5}{|c|}{ Burnt Area-1 } \\
\hline 10 & 2.360 & 0.011 & 4.624 & 6.995 \\
\hline 50 & 3.393 & 0.032 & 6.926 & 10.351 \\
\hline 100 & 2.297 & 0.017 & 5.587 & 7.901 \\
\hline 250 & 1.680 & 0.071 & 8.427 & 10.178 \\
\hline 350 & 1.913 & 0.183 & 9.494 & 11.590 \\
\hline \multicolumn{5}{|c|}{ Burnt Area-2 } \\
\hline 10 & 2.165 & 0.131 & 2.381 & 4.677 \\
\hline 50 & 1.303 & 0.059 & 5.154 & 6.516 \\
\hline 100 & 2.280 & 0.137 & 10.163 & 12.580 \\
\hline 250 & 2.148 & 0.152 & 8.954 & 11.254 \\
\hline 350 & 2.923 & 0.579 & 5.963 & 9.465 \\
\hline
\end{tabular}

On burnt area 2 it was found that the average C-stock tend to increase i.e. 4.677-12.580 ton ha ${ }^{-1}$ (Figure 12). The lowest number of biomass was found at a location close to the drainage at the initial observation distance $(10 \mathrm{~m})$, while the highest biomass was found at the farthest observation distance $(350 \mathrm{~m})$ from the drainage. Based on the results of the analysis of the correlation of carbon stocks with the distance of the observation plot from drainage, a very strong correlation $\left(\mathrm{R}^{2}=0.8131\right.$; Figure 13$)$ was noticed. This indicated that the relationship between the number of carbon stock stored increases with increasing distance. This may also be because farther the distance from the drainage, rare are the human activities. In addition, the number of C-stock that was available at a distance of $100 \mathrm{~m}$ from the drainage channel was because of the carrying out of felling of dead trees in the area after the fire, thus contributing to the stored C-stock.

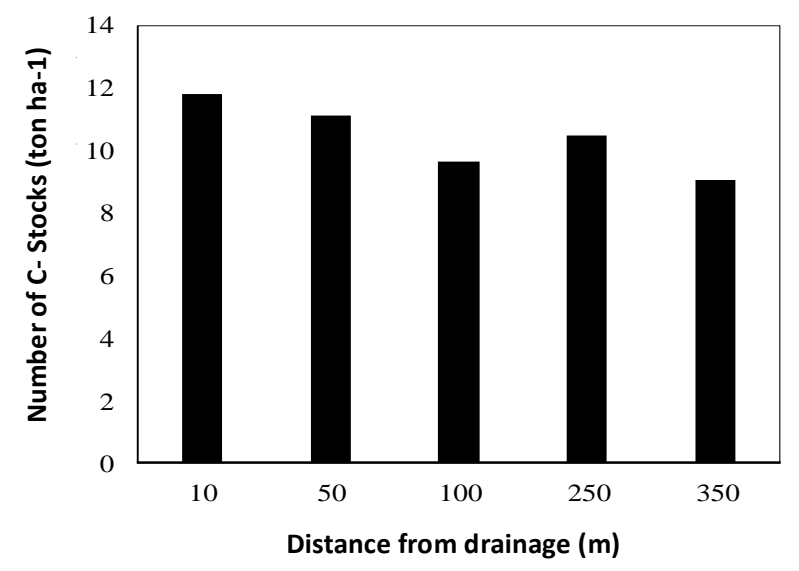

Figure 6. Number of C-stock from drainage distance in rubber plantations

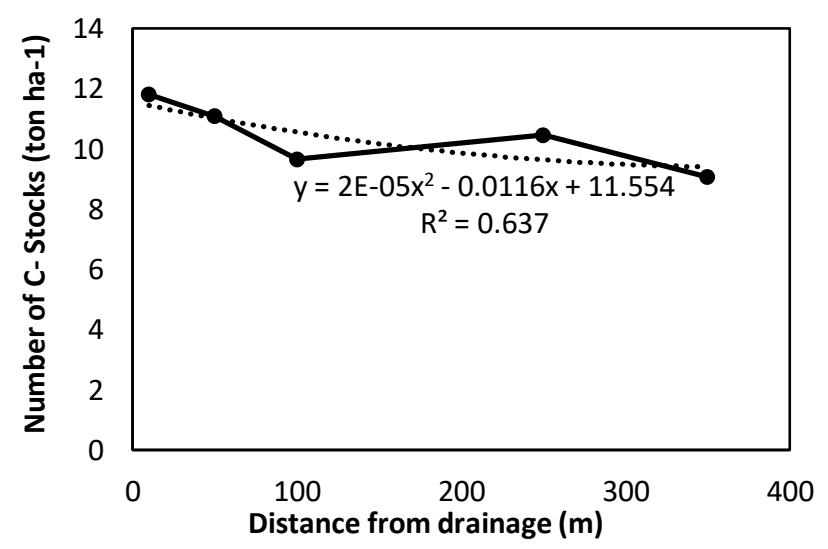

Figure 7. Correlation of the number of C-stock from drainage distance in a rubber plantation 


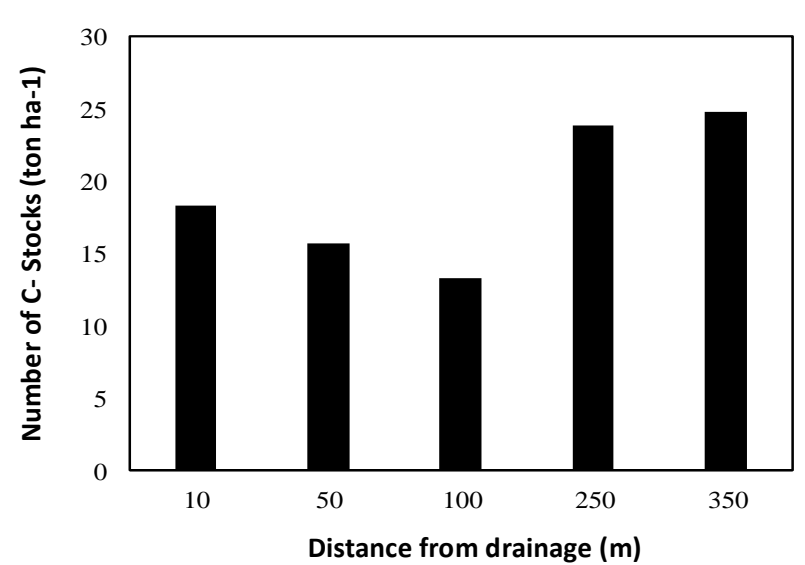

Figure 8. Number of C-stock from drainage distance in secondary forests

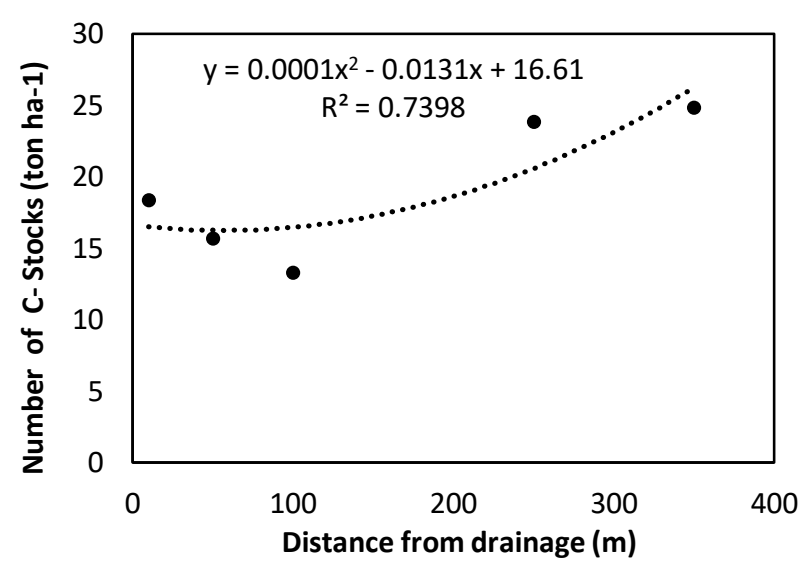

Figure 9. Correlation of C-stock number from drainage distance in secondary forests

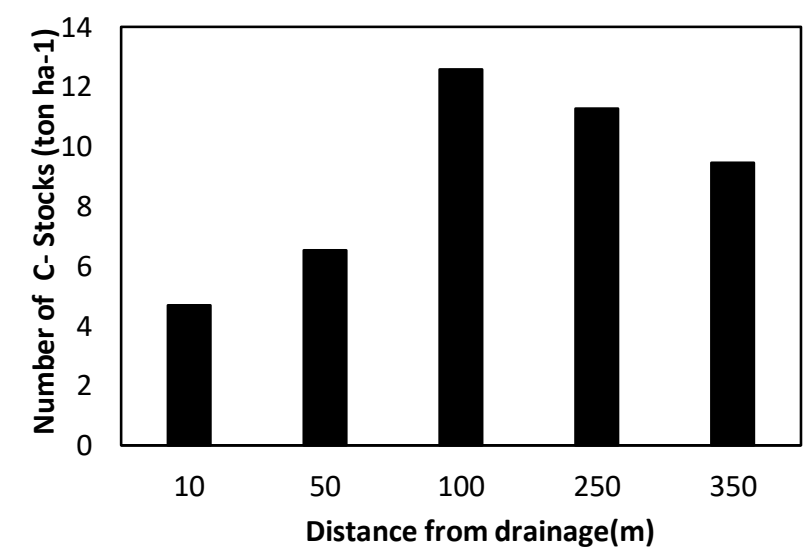

Figure 10. Number of C-stock from drainage distance in the Burnt Area-1

In conclusion, land use differences and fires occurred to affect the availability of C-stock. The high level of human activity (disturbance) in the area affected the availability of the existing C-stock. In general, the total C-Stock on land was found to be closer to the canal, and the C-Stock

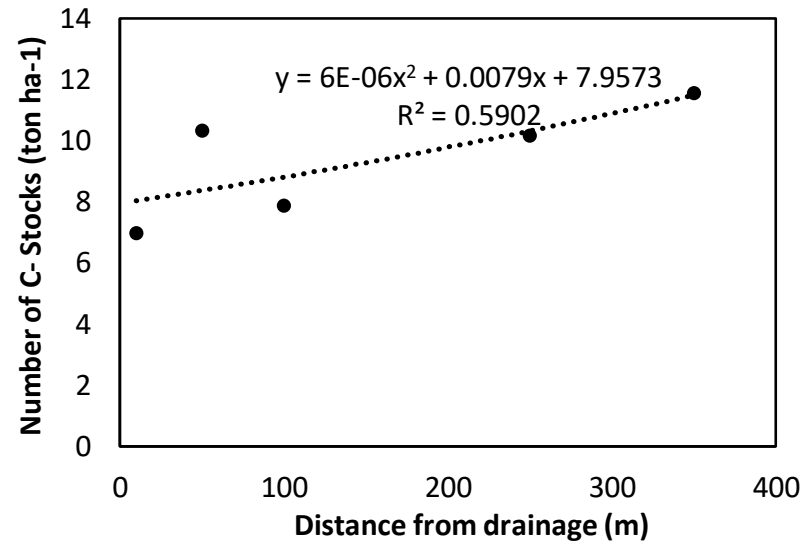

Figure 11. Correlation of C-stock number from drainage distance in Burnt Area-1

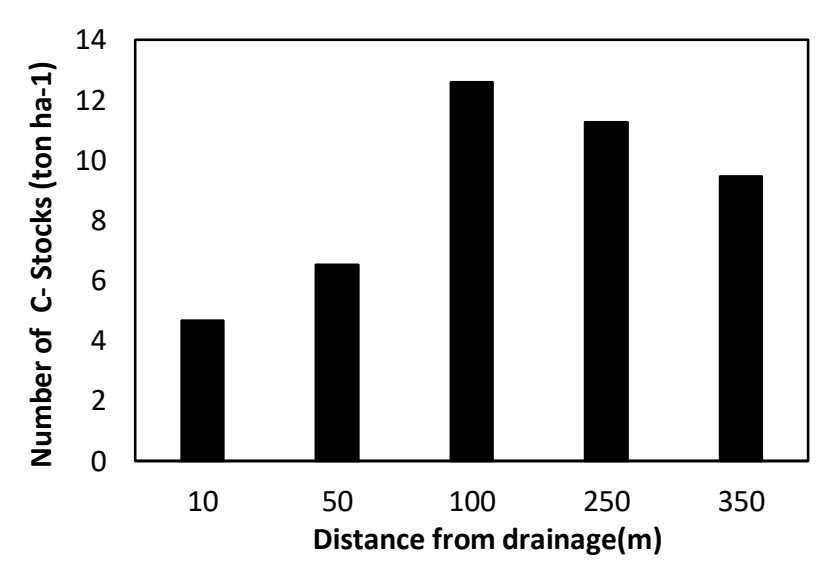

Figure 12. Number of C-stock of drainage distance in Burnt Area2

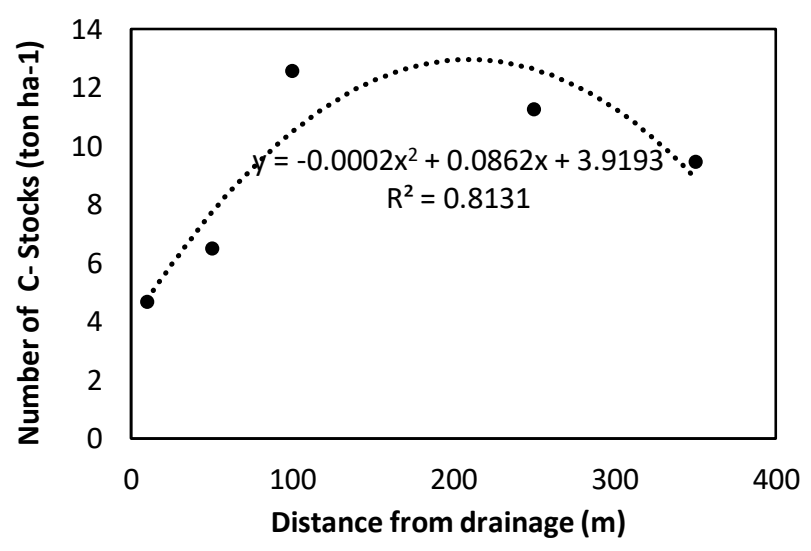

Figure 13. Correlation of C-stock numbers from drainage distance in burnt area

increased with the distance from the drainage. The further from the drainage, the activities carried out were reduced, which showed the effect of using a less intensive area. The quantity of C-stock in secondary forests ranged from 13.275 ton $\mathrm{ha}^{-1}-24.839$ ton $\mathrm{ha}^{-1}$, Burnt Area-1 ranged from 6.995 
ton ha-1 - 11.59 ton $\mathrm{ha}^{-1}$ and Burnt Area-2 ranged from 4.677 ton $\mathrm{ha}^{-1}-12.580$ ton $\mathrm{ha}^{-1}$. This was found to be different from land devoted to plantations such as rubber, where the $\mathrm{C}$ stock was found to be higher at the initial observation distance. Higher planting at the initial distance close to drainage was required for this type. The amount of C-stock was in the range of 9,064 ton $\mathrm{ha}^{-1}-11,805$ ton $\mathrm{ha}^{-1}$, and it could be possibly due to the intensive land use.

\section{ACKNOWLEDGEMENTS}

The author would like to thank the Ministry of Research, Technology, and Higher Education of the Republic of Indonesia for funding support of this research through the PMDSU Scholarship.

\section{REFERENCES}

Agus F. 2009. Cadangan, Emisi dan Konservasi Karbon pada Lahan Gambut.

http://balittanah.litbang.deptan.go.id/dokumentasi/lainnya/buku\%20b unga\%20rampai\%20kta\%2012-07\%20

Agus F, Subiksa IGM. 2008. Lahan Gambut: Potensi Untuk Pertanian Dan Aspek Lingkungan. Balai Penelitian Tanah. Badan Litbang Pertanian. World Agroforestry Centre. Bogor, Indonesia. [Indonesian]

Ariani Sudhartono A, Wahid A. 2014. Biomassa dan karbon tumbuhan bawah sekitar danau Tambling pada kawasan taman nasional Lore Lindu. Jurnal Warta Rimba 2 (1): 16-170. [Indonesian]

Arifin M. 2010. Kajian Sifat fisik tanah dan berbagai penggunaan lahan dalam hubungannya dengan pendugaan erosi tanah. Jurnal Pertanian MAPETA 12 (2): 72-144. [Indonesian]

Badan Standarisasi Nasional (BSN). 2011. SNI 7724: Pengukuran dan penghitungan cadangan karbon-Pengukuran lapangan untuk penaksiran cadangan karbon hutan (Ground Based Forest Carbon Accounting). Badan Standarisasi Nasional, Jakarta, Indonesia. [Indonesian]

Basuki I, Kauffman JB, Peterson J, Anshari G, Murdiyarso D. 2018. Land cover changes reduce net primary production in tropical coastal peatlands of West Kalimantan. Indonesia. Mitigation and Adapt Strategies Global Change 24 (4): 557-573. DOI: 10.1007/s11027-0189811-2.

Brown S. 1997. Estimating Biomass and Biomass Change of Tropical Forest - A Primer. FAO Forestry Paper 134. Food and Agriculture Organization of the United Nations, Rome.

Canadell JG, Pataki DE, Pitelka L. 2007. Saturation of the terrestrial carbon sink. In: Canadell JG, Pataki DE, Pitelka L (eds) Terrestrial Ecosystems in a Changing World. Berlin, Springer Verlag.

Chandler C, Cheney P, Trabaud L. Williams D. 1983. Fire in Forestry. Vol I.A Willey-Interscience Publication. New York.

Chung-Wang X, Ceulemans R. 2004. Allometric relationships for below and above ground biomass of young scots pines. For Ecol Manag 203 (1-3): 177-186.

Clement EG. 2015. New approach to restoration of shallow marginal peatlands. J Environ Manag 161: 417-430.

DeGroot WJ, Flannigan MD, Cantin AS. 2013. Climate change impact on future boreal fire regimes. For Ecol Manag 294: 35-44. DOI: 10.1016/j.foreco.2012.09.027.

Fuller M. 1991. Forest Fire: An Introduction to Wildland Fire Behaviour, Management, Fire Fighting and Prevention. Wiley Nature Edition. JohnWiley and Sons, Inc., New York.

Gibbs HK, Brown S, Niles JO, Foley JA. 2007. Monitoring and estimating tropical forest carbon stocks: making REDD a reality. Environ Res Lett 2 (4): 045023. DOI: 10.1088/1748-9326/2/4/045023.

Hairiah K, Ekadinata A, Sari RR, Rahayu. 2011. Pengukuran Cadangan Karbon. dari Tingkat Lahan ke Bentang Lahan. Edisi ke-2. World Agroforestry Centre, ICRAF SEA Regional Office, Bogor, Indonesia. [Indonesian]
Hooijer A, Silvius M, Wösten H, Page S. 2006. PEAT- $\mathrm{CO}_{2}$, Assessment of $\mathrm{CO}_{2}$ emissions from drained peatlands in SE Asia. Delft Hydraulics report Q3943. http://wetlands.or.id/PDF/buku/Peat\%20CO2.pdf [179-2021]

Huijnen V, Wooster MJ, Kaiser JW, Gaveau DLA, Flemming J, Parrington M, Inness A, Murdiyarso D, Main B, van Weele M. 2016. Fire carbon emissions over maritime south-east Asia in 2015 largest since 1997. Sci Rep 6 (1): 1-8. DOI: 10.1038/srep26886.

Intergovernmental Panel on Climate Change (IPCC). 2003. In: Penman J, Gystarsky M, Hiraishi T, Krug D, Kruger D, Pipatti R, Buendia L, Miwa K, Ngara T, Tanabe K, Wagner K (eds) Good Practice Guidance for Land Use, Land-Use Change and Forestry (GPG-LULUCF). National Greenhouse Gas Inventories Programme. IGES, Japan.

Intergovernmental Panel on Climate Change (IPCC). 2006. In: Eggleston HS, Buendia L, Miwa K, Ngara T, Tanabe K (eds) 2006 IPCC Guidelines for National Greenhouse Gas Inventories, National Greenhouse Gas Inventories Programme. IGES, Japan.

Koh LP, Miettinen J, Liew SC, Ghazoul J. 2011. Remotely sensed evidence of tropical peatland conversion to oil palm. Proc Nat Acad Sci 108 (12): 5127-5132. DOI: 10.1073/pnas.1018776108.

Leng GQT, Rayburg S. 2015. Climate change impact on meteorological, agricultural and hydrological drought in China. Global Planetatary Change 126: 23-34. DOI: 10.1016/j.gloplacha.2015.01.003.

Lillesand TM, Kiefer RW. 1990. Remote Sensing and Image Interpretation UGM Press. Yogyakarta, Indonesia.

Lubis AR. 2011. Pendugaan Cadangan Karbon Kelapa Sawit Berdasarkan Persamaan Alometrik di Lahan Gambut Kebun Meranti Paham, PT. Perkebunan Nusantara IV, Kabupaten Labuhan Batu, Sumatera Utara. [Skripsi]. Institut Pertanian Bogor, Bogor, Indonesia. [Indonesian]

Manuri S, Brack C, Nugroho NP, Hergoualc'h K, Novita N, Dotzauer H, Verchot L, Putra CAS, Widyasari E. 2014. Tree biomass equations for tropical peat swamp forest ecosystems in Indonesia. For Ecol Manag 334: 241-253. DOI: 10.1016/j.foreco.2014.08.031.

Mulyasana D. 2008. Kajian Keanekaragaman Jenis Pohon pada Berbagai Ketinggian Tempat di Taman Nasional Gunung Ciremai. Provinsi Jawa Barat. [Skripsi]. Institut Pertanian Bogor, Bogor, Indonesia. [Indonesian]

Muslihat L, Rais DS, Hasudungan F, Wibisono ITC. 2009. Kajian biofisika lahan gambut (luas, ketebalan, topografi, biodiversity, vegetasi, dan stok karbon) di lokasi kerja PT. Persada Dinamika Lestari (anak perusahaan PT Astra AgroLestari) di Kabupaten Hulu Sungai UtaraKalimantan Selatan. Laporan Teknis. Wetareas International Indonesia Programme. Bogor, Indonesia. [Indonesian]

Oldeman LR, Las I, Darwis. 1979. An agroclimatic map of Sumatra. Contr Res Inst Agric Bogor 52: 1-35.

Page SE, Banks CJ, Rieley JO. 2007. Tropical peatlands: distribution, extent and carbon storage - uncertainties and knowledge gaps. Peatlands Intl 2 (2): 26-27.

Page SE, Rieley JO, Banks CJ. 2011. Global and regional importance of the tropical peatland carbon pool. Glob Change Biol 17 (2): 798-818. DOI: 10.1111/j.1365-2486.2010.02279.x

Parish FA, Sirin D, Charman H, Joosten T, Minayeva M, Silvius, Stringer. 2007. Assessment on Peatlands, Biodiversity and Climate Change: Main Report. Global Environment Centre, Kuala Lumpur and Wetlands International, Wageningen Programme.

Radjagukguk B. 1997. Peat soils of Indonesia: location, classification and problem for sustainability. In: Riely J, Page SE. Biodiversity and Sustainability of Tropical Peatland. Samara Publishing Limited. Cardigan, UK.

Rahayu SB, Lusiana B, Noordwijk MV. 2007. Pendugaan cadangan karbon di atas permukaan tanah pada berbagai sistem penggunaan lahan di Kabupaten Nunukan, Kalimantan Timur. ICRAF, Bogor, Indonesia. [Indonesian]

Ravindranath NH, Ostwald M. 2008. Methods for estimating above ground biomass. In: Ravindranath $\mathrm{NH}$, Ostwald $\mathrm{M}$ (eds) Carbon Inventory Methods: Handbook for Greenhouse Gas Inventory, Carbon Mitigation and Roundwood Production Projects. Springer Science and Business Media B.V, Dordrecht. DOI: 10.1007/978-1-4020-6547-7.

Rieley JO, Wüst RAJ, Jauhiainen J, Page SE, Wösten H, Hoijer A, Siegert F, Limin S, Vasander H, Stahlhut. 2008. Tropical peatlands: carbon store. carbon gas emissions and contribution to climate change processes. Intl Peat Soc 148-181.

Ritzema HP. 2007. The role of drainage in the wise use of tropical peatlands. Carbon-climate-human interaction on tropical Peatland. Proceedings of the International Symposium and Workshop on tropical Peatland. Yogyakarta, Indonesia, 27-29 August 2007. 
Runtunuwu E, Kartiwa B, Kharmilasari K, Sudarman K, Nugroho WT, Firmansyah A. 2011. Dinamika elevasi muka air pada lahan dan saluran di lahan gambut. Jurnal RISET Geologi dan Pertambangan 21 (2): 63-74. DOI: 10.14203/risetgeotam2011.v21.47. [Indonesian]

Sulman BN, Desai AR, Schroeder NM. 2012. Impact of hydrological variations on modeling of peatland $\mathrm{CO}_{2}$ fluxes: Results from the North American carbon program site synthesis. J Geophys Res Biogeosci 117: G01031. DOI: 10.1029/2011JG001862.

Sutarta ES, Siregar HH, Harahap IY, Sugiyono Rahutomo S. 2006. Potensi Lahan untuk Kelapa Sawit di Indonesia. Pusat Penelitian Kelapa Sawit. Medan, Indonesia. [Indonesian]
Tresnawan H, Rosalina U. 2002. Pendugaan biomasa di atas tanah di ekosistem hutan primer dan hutan bekas tebangan (Study kasus di hutan Dusun Aro, Jambi). Jurnal Manajemen Hutan Tropika 8 (1): 15 29. [Indonesian]

Verwer CC, van der Meer PJ. 2010. Carbon pools in tropical peat forest: towards a reference value for forest biomass carbon in relatively undisturbed peat swamp forests in Southeast Asia. (Alterra-report; No. 2108). Alterra. https://edepot.wur.nl/160910 [17-9-2021]

Yahmani A. 2013. Study of carbon content in secondary natural forest in the Mandiangin Education Forest, Faculty of Forestry, Universitas Lambung Mangkurat. Universitas Lambung Mangkurat, Banjarbaru, South Kalimantan, Indonesia. [Indonesian] 